\title{
Oxolinic Acid-resistant Mutants of Bacillus subtilis
}

\author{
By J. M. VAZQUEZ-RAMOS† AND J. MANDELSTAM* \\ Microbiology Unit, Department of Biochemistry, University of Oxford, \\ Oxford OX1 $3 Q U, U . K$.
}

(Received 26 March 1981)

\begin{abstract}
Two mutants of Bacillus subtilis have been independently selected for resistance to oxolinic acid, an inhibitor of DNA gyrase. The mutations, designated $o x r-1$ and $o x r-2$, map very close to one another but are clearly separated from mutations in the genes for DNA gyrase. Many of the phenotypic properties of the mutants differ from those of a strain containing the gyrA mutation described by other workers. In particular, the oxr strains are as sensitive as the wild-type to inhibition by nalidixic acid on solid medium. In addition, experiments with DNA synthesis in toluenized cells show that the enzyme of the gyrA mutant is resistant to oxolinic acid, whereas DNA synthesis in the oxr mutants is as sensitive as it is in wild-type preparations. It is concluded that resistance to oxolinic acid is not due to an alteration in the DNA gyrase, but is more probably the result of an impaired uptake of the inhibitor.

Although growth of the mutants on agar plates is inhibited at high concentrations of oxolinic acid, lower concentrations (1-2 $\mu \mathrm{g} \mathrm{ml}^{-1}$ ) can be used to distinguish them from the wild-type. The oxr-1 and oxr-2 mutations define a new genetic locus and can be used as genetic markers in $B$. subtilis.
\end{abstract}

\section{INTRODUCTION}

Oxolinic acid and nalidixic acid are two closely related inhibitors which prevent synthesis of DNA by interacting with the gyrA subunit of the enzyme DNA gyrase. This is a topoisomerase which controls the extent of DNA supercoiling (Sugino et al., 1977; Gellert et al., 1977) and its action is necessary for DNA replication.

Sugino et al. (1977) have shown that DNA gyrase isolated from nalidixic acid-resistant strains of Escherichia coli is resistant to both oxolinate and nalidixate in in vitro assays. Gyrase has also been isolated from Micrococcus luteus (Liu \& Wang, 1978) and from Bacillus subtilis (Sugino \& Bott, 1980). However, in neither study was it shown that DNA gyrase isolated from nalidixic acid-resistant strains was resistant to both inhibitors.

In this paper we describe the independent isolation of two oxolinic acid-resistant strains which differ genetically and physiologically from the previously described nalidixic acid-resistant strains. The results presented show that the resistance to oxolinate is not due to an alteration of DNA gyrase. Instead, the evidence indicates that the permeability of the cells to oxolinate in these strains has been altered.

\section{METHODS}

Organisms. Bacillus subtilis NiI, a derivative of strain $168 \operatorname{trpC2}$, was used; it will be referred to as the wild-type. It is auxotrophic for thymine and tryptophan and carries a defective PBSX phage in its genome which does not induce lysis of the cells when DNA synthesis is inhibited (Karamata, 1968). Strains PB1706

† Present address: Facultad de Quimica D. E. Pg., Departamento de Bioquímica, Universidad Nacional Autónoma de México, Mexico 21 DF. 
(trpC2 hisB2 tyrA aroB2 nal3) and PB1707 (purA16 leu8 nal3) were kindly donated by Dr Mazza and are resistant to high concentrations of nalidixic acid $\left(300 \mu \mathrm{g} \mathrm{ml} \mathrm{m}^{-1}\right)$.

Growth. Casein hydrolysate (CH) medium was prepared as described by Sterlini \& Mandelstam (1969). CH medium was inoculated with a colony from a plate and grown overnight with shaking at $30^{\circ} \mathrm{C}$. The culture was then transferred to $37^{\circ} \mathrm{C}$ and allowed to grow at this temperature for at least two generations. Growth was followed by measuring the turbidity of the cultures at $600 \mathrm{~nm}$ using a Unicam SP600 spectrophotometer. Readings were converted to dry $\mathrm{wt} \mathrm{ml}^{-1}$ with a calibration curve relating turbidity to dry weight.

DNA synthesis. This was followed by measuring incorporation of $\left[\right.$ methyl $\left.{ }^{3} \mathrm{H}\right]$ thymidine into DNA. Cells were grown in $\mathrm{CH}$ medium containing radioactive thymidine $\left(0.2 \mu \mathrm{Ci} \mathrm{ml}^{-1}\right)$ and carrier thymidine $\left(20 \mu \mathrm{g} \mathrm{ml} l^{-1}\right)$. Samples $(1 \mathrm{ml})$ were taken at intervals and fixed in trichloroacetic acid (TCA) $(1 \mathrm{ml} ; 10 \%, \mathrm{w} / \mathrm{v})$. The samples were filtered by suction through glass-fibre filters (Whatman GF/C, $2.1 \mathrm{~cm}$ diam., $1.2 \mu \mathrm{m}$ pore size). The filters were then washed with TCA $(10 \mathrm{ml} ; 5 \%, \mathrm{w} / \mathrm{v})$ containing thymidine $\left(300 \mu \mathrm{g} \mathrm{ml}^{-1}\right)$ and then with ethanol $(10 \mathrm{ml} ; 96 \%, \mathrm{v} / \mathrm{v})$. They were dried in a vacuum oven at $80^{\circ} \mathrm{C}$ for $60 \mathrm{~min}$ and then transferred to plastic scintillation vials containing $5 \mathrm{ml}$ scintillation fluid [2-(4'-tert-butylphenyl)-5-(4"-biphenylyl)-1,3,4-oxadiazole (butyl-PBD); $0.5 \%$, w/v, in toluenel. Radioactivity was counted in a Wallace LKB 1215 Rack Beta scintillation counter, using the module for ${ }^{3} \mathbf{H}$.

Degradation of DNA. Cells were grown from a small inoculum in $\mathrm{CH}$ medium containing $\left[\right.$ methyl $\left.-{ }^{3} \mathrm{H}\right]$ thymidine $\left(0.5 \mu \mathrm{Ci} \mathrm{gl}^{-1}\right)$ and carrier thymidine $\left(20 \mu \mathrm{g} \mathrm{ml}^{-1}\right)$ to a density of about $0.06 \mathrm{mg}$ dry wt ml-1. They were harvested, washed once with sporulation medium (Sterlini \& Mandelstam, 1969) and then resuspended in $\mathrm{CH}$ medium containing excess unlabelled thymidine $\left(100 \mu \mathrm{g} \mathrm{ml}^{-1}\right)$. Nalidixic acid or oxolinic acid was then added and samples $(1 \mathrm{ml})$ were collected at intervals and added to tubes containing TCA $(1 \mathrm{ml} ; 10 \% \mathrm{w} / \mathrm{v})$. The suspensions were centrifuged and portions $(0.1 \mathrm{ml})$ of the supernatant were put on to glass-fibre filters (Whatman $\mathrm{GF} / \mathrm{B}, 2.1 \mathrm{~cm}$ diam). The filters were dried and counted.

Short-term viability. This term refers to viability in liquid medium over a period of a few hours. Cultures were grown in $\mathrm{CH}$ medium to a cell density of $0.06-0.10 \mathrm{mg}$ dry $\mathrm{wt}^{-1}$. Nalidixic acid or oxolinic acid was then added and samples $(0.1 \mathrm{ml})$ were taken at intervals for up to $4 \mathrm{~h}$. The samples were then diluted with sporulation medium and suitable dilutions $\left(10^{5}, 10^{6}\right.$ and $\left.10^{7}\right)$ were plated in duplicate on nutrient agar plates.

Long-term viability. This is what is generally referred to as 'viability', i.e. the ability of a cell to form a colony on solid medium. Brain heart infusion broth (BHIB; Oxoid) was inoculated with a small colony and grown at $37^{\circ} \mathrm{C}$ to a cell density of $0.14 \mathrm{mg}$ dry $\mathrm{wt} \mathrm{m}^{-1}$. Dilutions $\left(10^{2}\right.$ to $\left.10^{7}\right)$ were made in sporulation medium and samples were plated on nutrient agar plates containing oxolinic acid or nalidixic acid.

DNA synthesis in toluenized cells. The method was that described by Matsushita \& Sueoka (1974).

Transformation. Competent cells were prepared by the method of Ayad \& Barker (1969). For transformation, the technique of Ephrati-Elizur (1968) was used instead of using purified DNA. In this technique, donor cells are grown in BHIB into the stationary phase, and during this state they release DNA that can be taken up by competent recipient cells. A portion $(0.1 \mathrm{ml})$ of the donor suspension was added to $1 \mathrm{ml}$ recipient cells. The transformed cultures were washed at least three times with sporulation medium to avoid carry-over of amino acids from the BHIB.

$P B S I$-mediated transduction. Transducing lysates were prepared as described by Coote (1972), adapted from Karamata \& Gross (1970). The method of Takahashi (1963) was used for transduction.

Inhibitors. Oxolinic acid was a gift from B. Langley of Imperial Chemical Industries. Nalidixic acid was purchased from Calbiochem.

Isolation of NiI (oxr-1), NiI (oxr-2) and NiI (gyrA). Both NiI (oxr-1) and NiI (oxr-2) strains were derived frem Bacillus subtilis NiI (trpC2 thyA thyB) (Karamata, 1968). Although they show similar characteristics, the procedure of selection was different.

Nil (oxr-l) was obtained after repeated cycles of short-term killing of NiI cells in liquid medium. An exponential-phase culture of $\mathrm{NiI}$ in $\mathrm{CH}$ medium was treated with oxolinic acid $\left(10 \mu \mathrm{gl}^{-1}\right)$ when the density had reached $0.140 \mathrm{mg}$ dry $\mathrm{wt} \mathrm{m}^{-1}$. After $5 \mathrm{~h}$, when more than $95 \%$ of the cells had been killed, the culture was diluted 10 -fold and 100 -fold in fresh $\mathrm{CH}$ medium and incubated overnight; the treatment with oxolinic acid was then repeated. After eight cycles, the predominant population consisted of a resistant strain which was designated Nil (oxr-1).

Nil (oxr-2) was obtained by mutagenesis of NiI with ethyl methanesulphonate (EMS). NiI cells were grown in BHIB to a density of $0.12 \mathrm{mg}$ dry $\mathrm{wt}^{-1}$. EMS $(0.2 \mathrm{M}$ final concn) was then added to the cells and the culture was incubated for $30 \mathrm{~min}$. The cells were washed with sporulation medium and resuspended in BHIB, and the culture was grown overnight at $37^{\circ} \mathrm{C}$. The following day the cells were spread on to plates containing oxolinic acid $\left(5 \mu \mathrm{g} \mathrm{ml}^{-1}\right)$. Nil (oxr-2) was the genetically most stable colony of several picked.

Nil (gyrA) was obtained by introducing the gyrA gene of strain PB1707 into Nil. The procedure used was transformation by congression with $\operatorname{Trp}^{+}$by means of the Ephrati-Elizur technique (see above).

The mutation oxr-l was placed in an isogenic background by transferring it by congression with $\mathrm{His}^{+}$into strain GSY 1021 ( His $^{-}$Pur $^{-}$) and then back into NiI by congression with Trp ${ }^{+}$. 


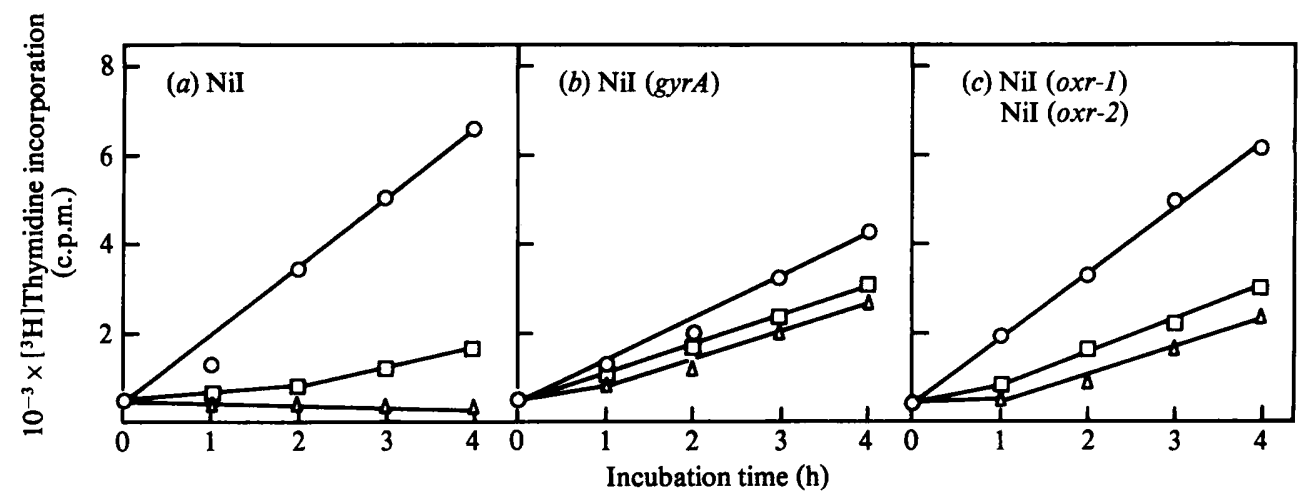

Fig. 1. Effect of oxolinic acid or nalidixic acid on DNA synthesis in strains NiI (oxr-1), Nil (oxr-2), NiI (gyrA) and $\mathrm{NiI}$ (wild-type). Each strain was grown in $\mathrm{CH}$ medium $(60 \mathrm{ml})$ containing [ $m e t h y l-{ }^{3} \mathrm{H}$ ]thymidine $\left(0.2 \mu \mathrm{Ci} \mathrm{m}^{-1}\right)$ and carrier thymidine $\left(20 \mu \mathrm{g} \mathrm{ml}^{-1}\right)$, to a cell density of about $0.06 \mathrm{mg}$ dry wt $\mathrm{ml}^{-1}$. Each culture was then split into three portions and received: no inhibitor (control) (O), oxolinic acid $\left(10 \mu \mathrm{g} \mathrm{ml}^{-1}\right)(\Delta)$, or nalidixic acid $\left(50 \mu \mathrm{g} \mathrm{ml} \mathrm{m}^{-1}\right)(\square)$. Identical results were obtained with NiI $($ oxr -1$)$ and $\mathrm{NiI}($ oxr-2).

\section{RESULTS}

\section{Effect of oxolinic acid and nalidixic acid on DNA synthesis}

Cells grown in $\mathrm{CH}$ medium in the presence of $\left[\right.$ methyl $\left.{ }^{3} \mathrm{H}\right]$ thymidine were treated with either oxolinic acid $\left(10 \mu \mathrm{g} \mathrm{ml}^{-1}\right)$ or nalidixic acid $\left(50 \mu \mathrm{gl}^{-1}\right)$. In the wild-type, nalidixic acid largely prevented incorporation for about $2 \mathrm{~h}$; synthesis of DNA was then resumed at a reduced rate (Fig. 1a). Oxolinic acid not only prevented net synthesis (Fig. 1a), but also produced degradation of DNA; this is more clearly shown in the experiments described in the following section. In NiI (gyrA), both inhibitors reduced DNA synthesis by about $50 \%$ (Fig. $1 b$ ). NiI (oxr-1) and NiI (oxr-2) behaved identically, exhibiting a considerably reduced rate of synthesis with both inhibitors after an initial lag (Fig. 1c).

\section{Effect of oxolinic acid and nalidixic acid on degradation of DNA}

Degradation of DNA in NiI, NiI (oxr-1), NiI (oxr-2) and NiI (gyrA) was compared by measuring the release of previously incorporated $\left[\right.$ methyl $\left.{ }^{3} \mathrm{H}\right]$ thymidine into the acid-soluble fraction. The wild-type control culture did not degrade any DNA during $4 \mathrm{~h}$, nor did any of the untreated mutants (Fig. 2). Both inhibitors produced appreciable degradation of DNA $(35-65 \%)$ in the wild-type; oxolinic acid caused some degradation (15-20\%) in all three mutants, but nalidixic acid did not (Fig. 2).

\section{Short-term viability}

Killing of cells by the inhibitors was measured in liquid medium over a period of $4 \mathrm{~h}$ (see Methods). In the wild-type culture, nalidixic acid killed about $85 \%$ of the cells in the first hour but there was no further fall in the next $3 \mathrm{~h}$ (Fig. $3 a$ ). In the three mutants treated with nalidixic acid the viable numbers remained stable at first and then began to increase (Fig. $3 b$, $c, d)$.

Oxolinic acid reduced the viability of the wild-type by $99 \%$ in less than $3 \mathrm{~h}$ (Fig. $3 a$ ). In oxolinic acid-treated NiI (gyrA) cultures, the numbers of viable cells remained constant for the duration of the experiment. This was in contrast to the behaviour of $\mathrm{NiI}(o x r-1)$ and $\mathrm{NiI}$ (oxr-2): in both these strains, there was an initial killing of about $70 \%$ followed by a slow recovery, which was reproducibly slower in $\mathrm{NiI}(o x r-2)$ than in $\mathrm{NiI}(o x r-1)$ (Fig. 3b, c,d). 


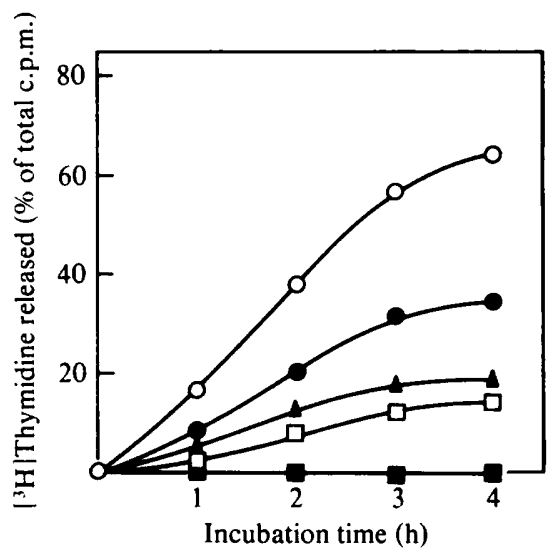

Fig. 2. Effect of oxolinic acid or nalidixic acid on degradation of DNA in strains NiI (gyrA), NiI (oxr-l), $\mathrm{NiI}$ (oxr-2) and Nil (wild-type). Each strain was grown in $\mathrm{CH}$ medium $(60 \mathrm{ml})$ containing

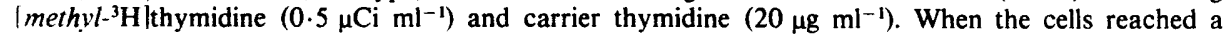
density of about $0.06 \mathrm{mg}$ dry $\mathrm{wt} \mathrm{ml}^{-1}$, the cultures were centrifuged, and the cells were washed once with sporulation medium containing thymidine $\left(100 \mu \mathrm{g} \mathrm{ml}^{-1}\right)$ and resuspended in $\mathrm{CH}$ medium containing thymidine in excess $\left(100 \mu \mathrm{g} \mathrm{ml}^{-1}\right)$. Each culture was split into three portions with additions as follows: oxolinic acid $\left(10 \mu \mathrm{g} \mathrm{ml}^{-1}\right)$, nalidixic acid $\left(50 \mu \mathrm{g} \mathrm{m}^{-1}\right)$ or none (control). Samples were taken at intervals and the radioactivity in the TCA-soluble fraction was measured. $\mathrm{O}, \mathrm{NiI}+$ oxolinic acid; $\mathbf{O}$. $\mathrm{NiI}+$ nalidixic acid; $\Delta, \mathrm{Nil}($ oxr -1$)+$ oxolinic acid and $\mathrm{NiI}($ oxr -2$)+$ oxolinic acid (results identical); $\square$. NiI (gyr) + oxolinic acid. $\square$, Controls of the four strains and also the mutants NiI (oxr-I), NiI $(o x r-2)$ and $\mathrm{NiI}(g y r A)$ treated with nalidixic acid.

\section{Long-term viability}

Again, there was a clear phenotypic difference between NiI (oxr-1) and NiI (oxr-2) on the one hand and Nil $(g y r A)$ on the other, when the strains were exposed to the inhibitors. Growth of the oxolinic acid-resistant strains was completely inhibited on plates containing nalidixic acid $\left(50 \mu \mathrm{g} \mathrm{ml}^{-1}\right)$. However, with $\mathrm{NiI}$ ( $\left.g y r A\right)$ the reduction in number of cells caused by nalidixic acid was much less (about 50\%), as expected (Table 1). Oxolinic acid caused viability to fall by three to four orders of magnitude in all three mutants.

\section{Effect of different concentrations of oxolinic acid on DNA synthesis and long term viability of NiI (oxr-I) and NiI}

From the experiments already described it was apparent that in mutants carrying oxr the capacity for DNA synthesis and long-term viability were both still seriously affected by the inhibitors. For the mutations to be genetically useful markers it was necessary to establish the conditions in which their phenotype could be clearly distinguished from that of the wild-type. Accordingly DNA synthesis and long term viability were measured in the presence of lower concentrations of oxolinic acid, to determine whether such a distinction could be made.

$\mathrm{NiI}($ oxr -1$)$ and NiI strains were exposed to different concentrations of oxolinic acid up to $10 \mu \mathrm{g} \mathrm{m}^{-1}$, and DNA synthesis was measured. In the wild-type NiI, oxolinic acid at 5 and $10 \mu \mathrm{g} \mathrm{ml}^{-1}$ completely stopped DNA synthesis and also induced the degradation of DNA. Even at $2.0 \mu \mathrm{g} \mathrm{ml}^{-1}$, DNA synthesis was greatly reduced (Fig. $4 a$ ). This concentration did not significantly affect DNA synthesis in NiI (oxr-1) (Fig. $4 b$ ). Higher concentrations $(5.0$ and $10 \mu \mathrm{g} \mathrm{ml}^{-1}$ ) retarded the onset of synthesis of DNA but recovery then occurred (Fig. 4 b). A similar result was obtained with NiI (oxr-2) (not shown).

The effect of different concentrations of oxolinic acid on long-term viability was then determined. Suitable dilutions of cultures were plated on agar plates containing oxolinic acid at $1.0,2.0$ and $3.5 \mu \mathrm{g} \mathrm{ml}^{-1}$. With both oxr strains, concentrations below $2.0 \mu \mathrm{g} \mathrm{ml}^{-1}$ gave viable counts that were 30 to $50 \%$ of those in the controls, while $3.5 \mu \mathrm{g} \mathrm{ml}^{-1}$ reduced viability 


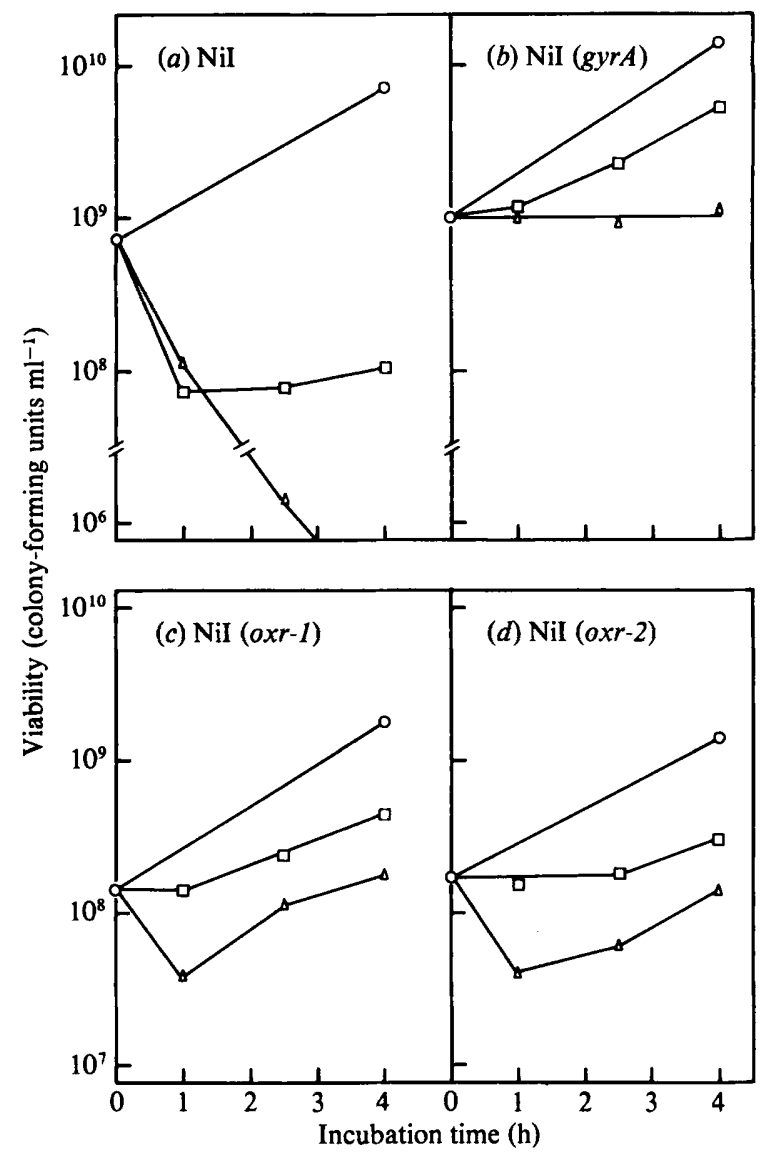

Fig. 3. Short-term viability in strains NiI (oxr-1), NiI (oxr-2), NiI (gyrA) and NiI (wild-type). Each strain was grown in $\mathrm{CH}$ medium $(30 \mathrm{ml})$ to a cell density of $0.06-0.10 \mathrm{mg}$ dry wt $\mathrm{ml}^{-1}$. Each culture was then split into three portions and received: no inhibitor (control) $(O)$, oxolinic acid $\left(10 \mu \mathrm{g} \mathrm{ml}^{-1}\right)(\triangle)$ or nalidixic acid $\left(50 \mu \mathrm{g} \mathrm{ml}^{-1}\right)(\square)$. Samples $(0.1 \mathrm{ml})$ were taken at intervals for up to $4 \mathrm{~h}$ and dilutions plated for viable counts (see Methods).

Table 1. Long-term viability in strains NiI (oxr-1), NiI (oxr-2), NiI (gyrA) and NiI (wild-type)

The four strains were grown in BHIB $(10 \mathrm{ml})$ to a cell density of $0.140 \mathrm{mg}$ dry $\mathrm{wt} \mathrm{ml}^{-1}$. Various dilutions were made of these cultures $\left(10^{2}\right.$ to $\left.10^{7}\right)$ and plating was done on nutrient agar plates containing oxolinic acid $\left(3.5 \mu \mathrm{g} \mathrm{m}^{-1}\right)$ or nalidixic acid $\left(50 \mu \mathrm{g} \mathrm{ml}^{-1}\right)$. Values are given as colonyforming units $\mathrm{ml}^{-1}$.

$\begin{array}{cccc}\text { Strain } & \text { No inhibitor } & \text { Oxolinic acid } & \text { Nalidixic acid } \\ \text { Nil (oxr-1) } & 9.3 \times 10^{8} & 8.1 \times 10^{5} & <10^{2} \\ \text { NiI (oxr-2) } & 1.2 \times 10^{9} & 1.2 \times 10^{6} & <10^{2} \\ \text { NiI }(\text { gyr } A) & 6.0 \times 10^{9} & 7.5 \times 10^{5} & 3 \times 10^{9} \\ \text { Nil } & 1.6 \times 10^{9} & <10^{2} & <10^{2}\end{array}$

by three orders of magnitude (Fig. 5). Wild-type $\mathrm{NiI}$ did not grow at any of the concentrations tested. This established that oxolinic acid at concentrations between 1 and $2 \mu \mathrm{g} \mathrm{ml}^{-1}$ could be used as a selective agent. 


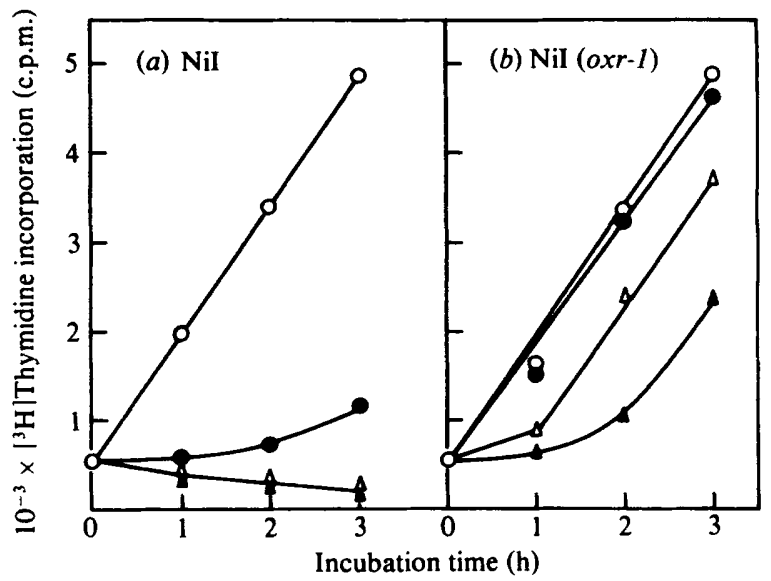

Fig. 4. Effect of different concentrations of oxolinic acid on DNA synthesis in strains NiI (wild-type) and $\mathrm{Nil}(o x r-1)$. Each strain was grown in $\mathrm{CH}$ medium $(100 \mathrm{ml})$ containing $\left[\right.$ methyl- $\left.{ }^{3} \mathrm{H}\right]$ thymidine $\left(0.2 \mu \mathrm{Ci} \mathrm{ml} l^{-1}\right)$ and carrier thymidine $\left(20 \mu \mathrm{g} \mathrm{ml}^{-1}\right)$, to a cell density of about $0.06 \mathrm{mg} \mathrm{dry} \mathrm{wt} \mathrm{ml}^{-1}$. Each culture was split into four portions receiving: no oxolinic acid (control) (O), $2.0 \mu \mathrm{g} \mathrm{ml}^{-1}(O)$ ), $5.0 \mu \mathrm{g} \mathrm{ml}^{-1}(\Delta)$ and $10 \mu \mathrm{g} \mathrm{ml} \mathbf{H}^{-1}(\boldsymbol{A})$. Samples were taken at intervals and DNA synthesis was followed (see Methods).

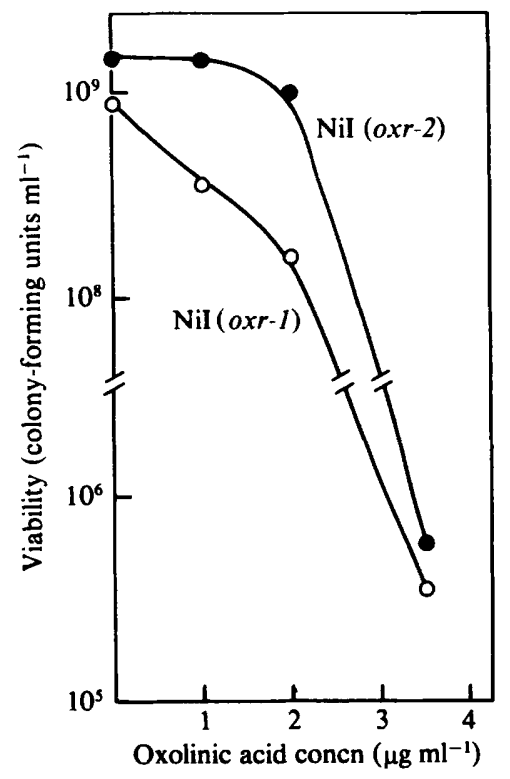

Fig. 5. Effect of different concentrations of oxolinic acid on long-term viability in strains NiI (oxr-1), $\mathrm{NiI}($ oxr-2) and Nil (wild-type). Each strain was grown in BHIB $(10 \mathrm{ml})$ to a cell density of $0.14 \mathrm{mg}$ dry $w t \mathrm{ml}^{-1}$. Dilutions $\left(10^{\circ}\right.$ to $\left.10^{7}\right)$ were made in sporulation medium and samples were plated on nutrient agar plates containing oxolinic acid at $1.0,2.0$ and $3.5 \mu \mathrm{g} \mathrm{ml}^{-1}$. The plates were incubated overnight at $42{ }^{\circ} \mathrm{C}$. O $\mathrm{Nil}(o x r-1) ; \mathrm{O}, \mathrm{Nil}(o x r-2)$. The wild-type $\mathrm{NiI}$ did not grow at any concentration of oxolinic acid tested, even when undiluted samples were plated.

\section{DNA synthesis in toluenized cells}

The experiments described, together with the finding that the oxr mutations do not map at the gyrA locus (see below), suggested that the mutations in the oxolinic acid-resistant strains had not affected the DNA gyrase but might have conferred a decreased permeability to 


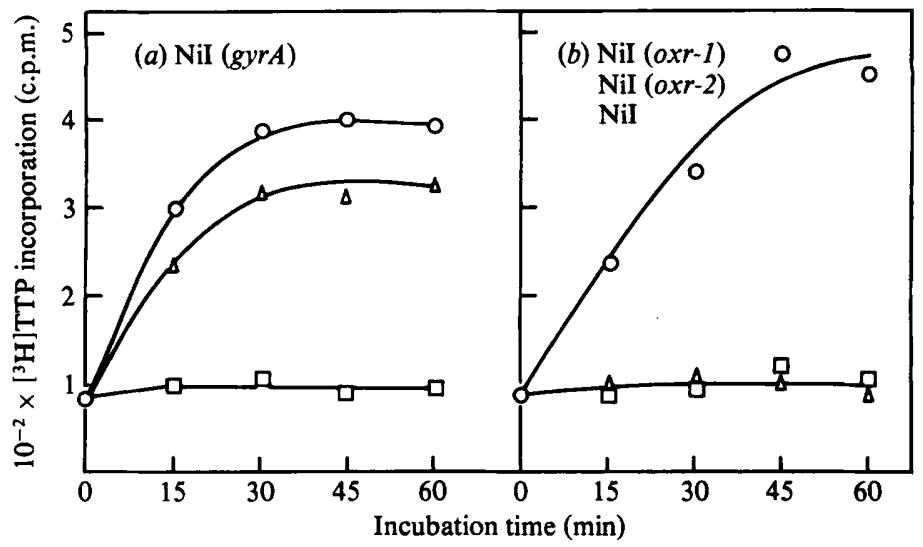

Fig. 6. DNA synthesis in toluenized cells of strains Nil (oxr-1), Nil (oxr-2), NiI (gyrA) and NiI (wild-type). Each strain was grown in $\mathrm{CH}$ medium $(50 \mathrm{ml})$ to a cell density of about $0.06 \mathrm{mg}$ dry wt $\mathrm{ml}^{-1}$. The cultures were centrifuged and the cells were washed with potassium phosphate buffer $(10 \mathrm{ml}$, $\mathrm{pH} 7.4)$ and then suspended in $1.0 \mathrm{ml}$ of the same buffer. Toluene $(10 \mu \mathrm{l})$ was added and the cells were agitated at $1 \mathrm{rev} . \mathrm{s}^{-1}$ for $10 \mathrm{~min}$ at room temperature. Then the cells were cooled at $4{ }^{\circ} \mathrm{C}$ for $5 \mathrm{~min}$. The temperature for measuring DNA replication was $37^{\circ} \mathrm{C}$; replication was measured as follows. A $0.1 \mathrm{ml}$ sample of toluenized cells was added to $0.4 \mathrm{ml}$ of incubation mixture to form a final reaction mixture containing 70 mM-potassium phosphate buffer (pH 7.4), 13 mM-MgSO, $1.3 \mathrm{~mm}$-ATP, $33 \mu \mathrm{M}$-dGTP, $33 \mu \mathrm{M}$-dATP, $33 \mu \mathrm{M}$-dCTP, $33 \mu \mathrm{M}$-TTP, $2 \mathrm{mM}$-dithiothreitol and $2 \mu \mathrm{Ci}\left[{ }^{3} \mathrm{H}\right.$ ]TTP. No ATP was added to samples in which 'repair' DNA synthesis was to be determined. Samples $(50 \mu \mathrm{l})$ were removed at $15 \mathrm{~min}$ intervals for $1 \mathrm{~h}$, mixed with herring DNA $\left(2 \mathrm{mg} \mathrm{ml}^{-1}\right)$ and precipitated with TCA (10\%, $\left.2 \mathrm{ml}\right)$. The samples were chilled in ice for $30 \mathrm{~min}$ and then filtered through glass-fibre filters (Whatman GF/C, $2.1 \mathrm{~cm}$ diam.), and washed with TCA $(10 \%, 10 \mathrm{ml})$ and ethanol $(96 \%, 10 \mathrm{ml})$. The filters were dried in a vacuum oven $\left(80^{\circ} \mathrm{C}, 60 \mathrm{~min}\right)$ and counted. $\mathrm{O}$, Control; $\triangle$, oxolinic acid $\left(100 \mu \mathrm{g} \mathrm{ml}^{-1}\right)$; $\square$, no ATP. $\mathrm{NiI}(o x r-1), \mathrm{NiI}(o x r-2)$ and the wild-type NiI were equally inhibited by oxolinic acid.

oxolinic acid. To test this hypothesis, DNA synthesis was followed in vitro using cells which had been made permeable by treatment with toluene.

The concentration of oxolinic acid necessary to stop DNA synthesis in wild-type cells under these conditions was 10 -fold higher than that needed in vivo. A similar effect in toluenized cells of $E$. coli has been reported by Staudenbauer (1976), who measured the inhibition of DNA synthesis by oxolinic acid. Strains NiI, NiI (oxr-1), NiI (oxr-2) and NiI (gyrA) were tested. To show that DNA synthesis was due to the action of DNA polymerase III and not to repair synthesis, controls were included in which either ATP was excluded from the reaction mixture or 6-( $p$-hydroxyphenylazo)uracil (HPUra), a specific inhibitor of DNA polymerase III (Gass et al., 1973) was added at a concentration of $50 \mu \mathrm{g} \mathrm{ml}^{-1}$. Both treatments prevented the synthesis of any significant amount of DNA. The result clearly showed that NiI ( $g y r A)$ could synthesize DNA in the presence of a high concentration of oxolinic acid, and the amount synthesized was similar to that in control cells (Fig. $6 a$ ). The oxolinic acid-resistant strains and the wild type NiI were equally inhibited by oxolinic acid (Fig. 6b).

\section{Mapping of oxr-1, oxr-2 and gyrA}

Strain PB1706 is a nalidixic acid-resistant strain with high resistance to the inhibitor (up to $300 \mu \mathrm{g} \mathrm{ml}^{-1}$ ). Its gyrA mutation has been mapped between purA (39\% cotransduction) and cys $A$ ( $52 \%$ cotransduction) by Canosi \& Mazza (1974). In our experiments the values were roughly similar: $30 \%$ and $42-44 \%$ respectively (Table 2 ).

To compare the locations of oxr-1 and oxr-2 with that of gyrA, these strains were also mapped by PBS1-mediated transduction. Table 2 shows the strains used as recipients and the linkage values obtained with different auxotrophic markers. The oxr mutations were 
Table 2. Linkage of gyrA, oxr-1 and oxr-2 to different markers

PBS1-mediated transduction (see Methods) was employed to map the different strains. As recipients, two cy's and two purA auxotroph strains were used.

Donor

PB $1706($ gyrA $)$
Recipient

QB944 (cysA purA trpC2)

BD112 (cysA)

GSY 1021 ( purA hisB)

Nil $(o x r-1)$

QB944 (cysA purA trpC2)

BD112 (cysA)

GSY 1021 (purA hisB)

QB944 (cy'sA purA trpC2)

BD112 (cysA)

GSY 1021 ( purA hisB)
Selected
marker

$c y s^{+}$

pur ${ }^{+}$

cys ${ }^{+}$pur ${ }^{+}$

$\mathrm{cys}^{+}$

pur ${ }^{+}$

cyst

pur ${ }^{+}$

cys ${ }^{+}$pur ${ }^{+}$

$c y s^{+}$

pur ${ }^{+}$

$c y s^{+}$

pur ${ }^{+}$

cys ${ }^{+}$pur ${ }^{+}$

cys ${ }^{+}$

pur ${ }^{+}$
No. of gyrA or $o x r$ transductants/total

$38 / 90$

$34 / 113$

$43 / 49$ and $68 / 70$

$38 / 86$ and $59 / 133$

$21 / 88$

$16 / 127$

$0 / 127$

$0 / 58$

$31 / 163$ and $26 / 147$

$0 / 120$

$15 / 89$

$0 / 127$

$0 / 60$

$22 / 115$ and $15 / 89$

$0 / 120$
Linkage

(\%)

42

30

44 and 44

24

13

0

19 and 18

0

17

0

19 and 17

0

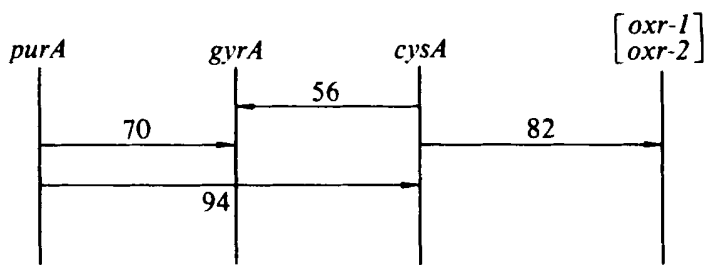

Fig. 7. Linkage of $o x r-1$ and $o x r-2$ to $c y s A$. PBS 1 -mediated transduction was used to locate $o x r-I$ and $o x r-2$ in relation to the previously mapped cys $A$, purA and gyrA markers. The numbers represent transduction map units (100 - percentage co-transduction). The linkage of purA to cys $A$ was obtained from Dubnau et al. (1967).

completely unlinked to purA and had low linkage to cysA. When selection was made simultaneously for $c y s^{+}$and $p u r^{+}$, the $o x r$ mutations were excluded. They clearly did not lie between the cysA and purA markers but were close to each other. Figure 7 shows the position of $o x r-1$ and $o x r-2$ in the map and their distance from $c y s A$. They are clearly separated from gvrA.

\section{DISCUSSION}

The phenotypic and genetic properties of strains resistant to oxolinic acid and those resistant to nalidixic acid can be summarized as follows.

1. The mutations oxr-1 and oxr-2 (which seem to be close together) on the one hand and gyrA on the other have quite different chromosomal locations.

2. In short-term viability experiments, gyrA mutants are even more resistant to oxolinic acid than oxr mutants.

3. The oxolinic acid-resistant strains show no resistance to nalidixic acid in long term viability experiments.

4. Strains containing gyrA are able to synthesize DNA in vitro in the presence of a high concentration of oxolinic acid, whereas. DNA synthesis in the oxolinic acid-resistant strains under the same conditions is effectively inhibited. 
These results appear to rule out the possibility that the oxr mutations have altered the structure of DNA gyrase. Instead, the evidence obtained suggests that the oxr mutations have reduced the permeability of cells to oxolinic acid so that the cells become resistant to low concentrations of the inhibitor (i.e. below $5 \mu \mathrm{g} \mathrm{ml}^{-1}$ ). Since there is also some cross-resistance to nalidixic acid, mainly observed when degradation of DNA or short-term viability are measured, it is possible that oxolinic acid and nalidixic acid share a common transport mechanism.

Although the degree of resistance to oxolinic acid is not very high, it is sufficient to allow the oxr mutations to be used as genetic markers in genetic analysis.

J. Vazquez-Ramos gratefully acknowledges the receipt of a grant from CONACYT (MEXICO) and from the Universidad Nacional Autónoma de México. This work was supported by the Science Research Council.

\section{REFERENCES}

AYAD, S. R. \& BARKER, G. R. (1969). The integration of donor and recipient deoxyribonucleic acid during transformation of Bacillus subtilis. Biochemical Journal 113, 167-174.

Canosi, U. \& MAzzA, G. (1974). Genetic location of the mutation determining nalidixate resistance in Bacillus subtilis. International Research Communication System (Microbiology, Parasitology and Infectious Disease) 2, 1679.

Coote, J. G. (1972). Sporulation in Bacillus subtilis. Genetic analysis of oligosporogenous mutants. Journal of General Microbiology 71, 17-27.

Dubnau, D., Goldthwaite, C., Smith, I. \& MARMUR, J. (1967). Genetic mapping in Bacillus subtilis. Journal of Molecular Biology 27, 163-185.

Ephrat1-Elizur, E. (1968). Spontaneous transformation in Bacillus subtilis. Genetical Research 11, 83-96.

Gass, K. B., Low, R. L. \& Cozzarelli, N. R. (1973). Inhibition of a DNA polymerase from Bacillus subtilis by hydroxyphenylazopyrimidines. Proceedings of the National Academy of Sciences of the United States of America 70, 103-107.

Gellert, M., Mizuuchi, K., O'Dea, M. H., IтOH, T. \& TomizAwA, I. J. (1977). Nalidixic acid resistance: a second genetic character involved in DNA gyrase activity. Proceedings of the National Academy of Sciences of the United States of America 74, 4772-4776.

KaramatA, D. (1968). Genetic control of deoxyribonucleic acid synthesis in Bacillus subtilis. Ph.D. thesis, University of London.

KaramatA, D. \& Gross, J. D. (1970). Isolation and genetic analysis of temperature-sensitive mutants of Bacillus subtilis defective in DNA synthesis. Molecular and General Genetics 108, 277-287.

LiU, L. F. \& WANG, J. C. (1978). Micrococcus luteus DNA gyrase: active components and a model for its supercoiling of DNA. Proceedings of the National Academy of Sciences of the United States of America 75, 2098-2102.

Matsushita, T. \& Sueoka, N. (1974). Tests for deoxyribonucleic acid synthesis in toluenized Bacillus subtilis cells. Journal of Bacteriology 118 , 974-979.

Staudenbauer, W. L. (1976). Replication of Escherichia coli DNA in vitro: inhibition by oxolinic acid. European Journal of Biochemistry 62, 491497.

Sterlini, J. M. \& Mandelstam, J. (1969). Commitment to sporulation in Bacillus subtilis and its relationship to the development of actinomycin resistance. Biochemical Journal 113, 29-37.

SugINo, A. \& Botr, K. F. (1980). Bacillus subtilis deoxyribonucleic acid gyrase. Journal of Bacterio$\log y$ 141, 1331-1339.

Sugino, A., Peebles, C. L., Kreuzer, K. N. \& Cozzarelli, N. R. (1977). Mechanism of action of nalidixic acid: purification of Escherichia coli nalA gene product and its relationship to DNA gyrase and a novel nicking-closing enzyme. Proceedings of the National Academy of Sciences of the United States of America 74, 4767-4771.

Takahashi, I. (1963). Transducing phages for Bacillus subtilis. Journal of General Microbiology 31, 211-217. 